\section{OIT Seeks Proposals, Fosters Partnerships}

The Department of Energy (DOE) published a report, Office of Industrial Technologies: Enhancing the Competitiveness, Efficiency, and Environmental Quality of American Industry Through Technology Partnerships, to encourage basic, energyintensive industries to develop an energyefficient vision for the 21st century. The "Industries of the Future" initiative involves the chemicals, petroleum refining, forest products, steel, aluminum, metal casting, and glass industries. After the industries define technology needs to meet their vision, DOE's Office of Industrial Technologies (OIT) fosters partnerships among private industry, government, universities, and other organizations to develop these technologies. Many of the technologies will save energy, reduce waste, and increase competitiveness. The partners share the costs and the risks of the research and pool their knowledge and capabilities to accelerate the technology development.

The report describes OIT's activities with industry partners. It discusses trends in industrial energy use and analyzes issues facing industry. The strategic initiative, the "Industries of the Future," is explained in detail. This initiative focuses on energy-intensive industries that account for more than $80 \%$ of the manufacturing sector's energy usage. The report examines the energy and environmental characteristics of these industries and describes strategic visions and technology roadmaps that have been developed by the industries. Profiles of selected OIT research and development partnerships highlight current successes, including statistics on potential savings, employment, and energy and environmental benefits.

To obtain a copy of the report, contact the National Renewable Energy Lab. at 303-275-4363, or U.S. Department of Energy, Efficiency and Renewable Energy Customer Service Center, P.O. Box 3048, Merrifield, VA 22116; 1-800-DOE-EREC; 1-800-273-2957 (hearing impaired); or email energyinfo@delphi.com. The OIT website is http://www.oit.doe.gov/.

\section{NAS Takes Science to the Public}

In order to increase the public's understanding of science, the National Academy of Sciences (NAS) has established a program to encourage scientists and the media to communicate about the nature of science and its processes. Too often, science is reported as bare facts or findings. Rarely is much context given for how the questions were asked, how the experiment was designed, and how the observations were made and interpreted. Without such context, the lay public may not recognize the nature and processes of science.

The program, carried out through the NAS Office on Public Understanding of Science, will focus on activities such as studies and surveys, public events, television and films, and multimedia projects. Its first major undertaking, Beyond Discovery: The Path from Research to Human Benefit, is a series of "case studies" that examine the origins of recent technological and medical advances. Each reveals the role played by basic science, the results of which could not have been anticipated when the original research was done. The first three publications in the series-on ozone depletion, the global positioning system, and "Modern Communication: The Laser and Fiber-Optic Revolution" - are on the Internet at http://www2.nas.edu/bsi/218e.html/.

The program expects to enlist more scientists in efforts to communicate to a broad public; establish links between scientists and the media, including filmmakers and producers; and develop tools and resources-focusing on the Internet-to conduct successful outreach activities. The program is overseen by an advisory committee chaired by Nobel laureate Dudley Herschbach of Harvard University. Further information is available at http://www2.nas.edu/opus/.

\title{
PUBLIC AFFAIRS FORUM
}

\section{Assessing Foreign Involvement in U.S. R\&D}

In the summer of 1989, Sheldon Weinig, Chief Executive Officer of Materials Research Corporation (MRC), was between a rock and a hard place. His company, a pioneer in sputtering technology and leading supplier of sputtering material and machines used to manufacture semiconductor chips, was heavily indebted yet desperately needed more money to develop the next generation of sputtering machines. Unable to find U.S. investors willing to ante up, Weinig turned to Sony Corporation. In short order, Sony acquired MRC for $\$ 58$ million, retained Weinig as vice chair of Sony Engineering and Manufacturing of America, and began investing heavily in MRC's U.S. research and development (R\&D) and manufacturing operations. In response, the U.S. press and other opinion leaders decried the loss of "a national treasure," and chastised Weinig for the "bargain price" offered to the Japanese company.
Nearly a decade later MRC remains a leading U.S.-based supplier of semiconductor materials. Its equipment business has been diversified to serve more directly the production needs of its Japanese parent. However, questions raised by the 1989 $\mathrm{MRC} /$ Sony deal about the costs and benefits of foreign involvement in U.S. R\&D have kept their edge. According to a National Academy of Engineering study, Foreign Participation in U.S. Research and Development: Asset or Liability? (National Academy Press, Washington, DC, 1996), reported in the September 1996 MRS Bulletin (page 14), foreign participation in U.S.-based research activity has grown apace since the late 1980s. By acquiring or establishing R\&D performing companies in the United States, foreign firms increased their share of total privately funded U.S. R\&D from $11 \%$ to $16 \%$ between 1988 and 1994, obtaining in 1994 a performance of $\$ 15.6$ billion worth of R\&D and employment of over 105,000 scientists and engineers in U.S.-based R\&D activity. Throughout this period, the U.S. materials research community has maintained, by a number of measures, one of the highest levels of foreign involvement of any segment of the U.S. R\&D enterprise. It is estimated that foreign institutions accounted for less than $2 \%$ of all sponsored research at U.S. universities and federal laboratories in 1994 . As of the early 1990 s, about $12 \%$ of all companies involved in all fields of research ( 1 in 10 companies in advanced materials research) at U.S. universityindustry research centers were foreignowned.

Foreign graduate students, postdoctoral researchers, and other visiting researchers are the main instruments of foreign involvement in publicly funded research at U.S. universities and federal laboratories. In 1994, foreign nationals constituted roughly $24 \%$ of all graduate students, $40 \%$ 


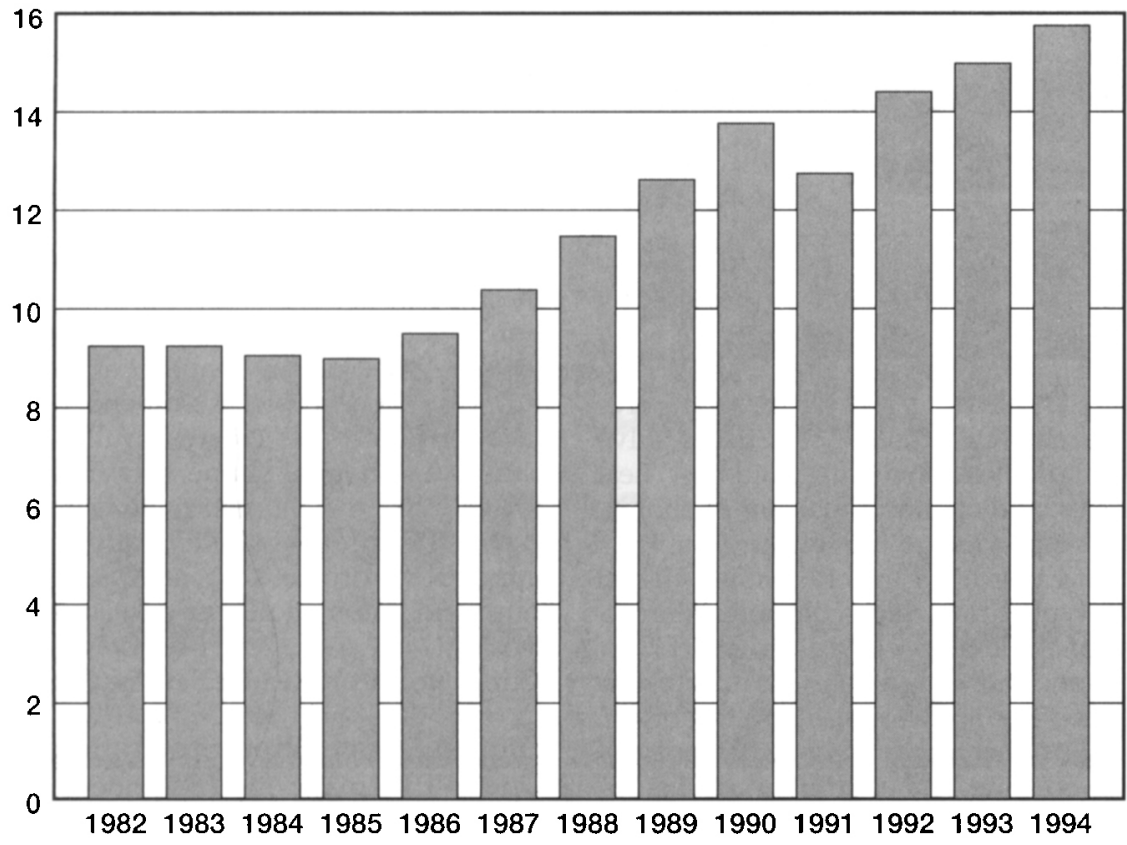

R\&D Spending by U.S. Affiliates of Foreign-Owned Firms as a Percentage of All Privately Funded U.S. R\&D, 1982-1994. (Sources: National Science Board [1996] and U.S. Department of Commerce [1996].) rules for international investment, a Multilateral Agreement on Investment (MAI), that seeks to address many critical market access issues.

Clearly, the United States cannot close the door to foreign investment or foreign researchers without doing serious harm to the nation's research enterprise as well as inflicting unacceptable costs on its citizens. The internationalization of $R \& D$ is a powerful, relentless trend. The fear of foreign involvement in the nation's economy and $R \& D$ system will no doubt continue to rise and $\mathrm{ebb}$ as it has in the past in response to various economic, technological, and societal challenges. Throughout, one can hope that U.S. policymakers stand by their choice to embrace the powerful trend of internationalization and work with it to amplify its benefits and manage its risks.

PROCTOR P. REID

Proctor P. Reid, associate director of the National Academy of Engineering's Program Office, served as study director for the Academy's three-year study of foreign participation in U.S. REDD. of doctorate recipients, and $52 \%$ of all postdoctoral researchers in science and engineering at U.S. universities. Within U.S. materials engineering departments alone, foreign nationals represent over $58 \%$ of postdoctoral researchers and $37 \%$ of all graduate students.

While growing dependence of U.S. universities on foreign-born students and faculty raises troubling questions about the United States' ability to "grow its own" scientists and engineers, foreign students and long-term visiting researchers are an indispensable asset to U.S. university and federal laboratory research. Foreign graduate students and postdoctoral researchers represent the "workhorses" of many university-based advanced research projects, and many subsequently join the U.S. industrial R\&D work force. Foreign nationals currently constitute over $10 \%$ of all employed $\mathrm{PhD}$ graduate engineers in the United States.

Overall, the U.S. affiliates of foreignowned firms import significantly more codified technology from their parent companies than they export. In many sectors, affiliates import significant amounts of advanced production technology from abroad (i.e., technology and know-how that have helped increase productivity in many U.S.-based industries). In addition to these technology imports, affiliates also underwrite, develop, apply, and diffuse a great deal of technology and know-how within the United States. Indeed, the
Defense Science Board ultimately applauded the Sony/MRC deal for maintaining U.S. production of (and assured Department of Defense access to) an adequate supply of sputtering materials.

While the net benefits of foreign participation in U.S. R\&D seem difficult to deny, the policy-related barriers encountered by U.S.-owned companies attempting to access R\&D assets abroad have affected the cost-benefit calculus of many U.S. observers. Among the policy issues raised by foreign $R \& D$ participation, that of reciprocal or equitable international access to national R\&D assets provides perhaps the best, most immediate opportunity for policy missteps by the United States and its trading partners. Unilateral actions aimed at equalizing access among national $R \& D$ systems, either by forcing open R\&D enterprises abroad or restricting foreign access to U.S.-based R\&D, are likely to discourage more "good" foreign investment in the United States than "bad." Moreover, such actions would undercut long-standing U.S. efforts to "liberalize" international markets through bilateral and multilateral negotiations-a particularly counterproductive move at a time when member countries of the Organization for Economic Cooperation and Development (27 of the world's leading industrialized countries, including the United States) are midstream in the negotiation of a set of internationally agreed

\section{Advanced Chemicals \& Materials Processing $\infty$}

- Electronic Grade Red Phosphorus

- GaN Powder \& submillimeter size single crystals

- InP polycrystalline charge, single crystals, wafers

- Bulk growth of III-V compound crystals with custom doping \& orientation

- R\&D Consulting Services for the Electronics Materials Industry

- Outsource and/or subcontract R\&D and manufacturing services

- Materials Purification

- Custom Single Crystals

- Custom Equipment Design

Visit us at Booth 319 at the Spring MRS Exhiblt, Aprll 1-3, 1997

Parke Mathematical Laboratories 450 Cheimsford Street Lowell, MA 01851

(508) 934-0854 FAX (508) 934-0731 E-mail: pmleparkemath.com Web Site: hitp://www.parkemath.com

Circle No. 23 on Reader Service Card. 